\title{
Quantitative detection of tetracycline-resistant microorganisms in conventional and organic beef, pork and chicken meat
}

Mónica Guarddon, José M. Miranda, José A. Rodríguez, Beatriz I. Vázquez, Alberto Cepeda \& Carlos M. Franco

To cite this article: Mónica Guarddon, José M. Miranda, José A. Rodríguez, Beatriz I. Vázquez, Alberto Cepeda \& Carlos M. Franco (2014) Quantitative detection of tetracycline-resistant microorganisms in conventional and organic beef, pork and chicken meat, CyTA - Journal of Food, 12:4, 383-388, DOI: $10.1080 / 19476337.2014 .892030$

To link to this article: https://doi.org/10.1080/19476337.2014.892030

() 2014 Taylor \& Francis

Submit your article to this journal ๘

View related articles $\sqsubset$

Citing articles: 4 View citing articles $\sqsubset$
Published online: 24 Jun 2014.

Џll Article views: 740

View Crossmark data $₫$ 


\title{
Quantitative detection of tetracycline-resistant microorganisms in conventional and organic beef, pork and chicken meat
}

\section{Detección cuantitativa de microorganismos resistentes a la tetraciclina en carne convencional y ecológica de ternera, cerdo y pollo}

\author{
Mónica Guarddon $^{\mathrm{a}}$, José M. Miranda ${ }^{\mathrm{a}}$, José A. Rodríguez ${ }^{\mathrm{b}}$, Beatriz I. Vázquez ${ }^{\mathrm{a}}$, Alberto Cepeda ${ }^{\mathrm{a}}$ and Carlos M. Franco ${ }^{\mathrm{a} *}$ \\ ${ }^{a}$ Laboratorio de Higiene, Inspección y Control de Alimentos, Departamento de Química Analítica, Nutrición y Bromatología, Facultad \\ de Veterinaria, Universidad de Santiago de Compostela, 27002 Lugo, Spain; ${ }^{b}$ Centro de Investigaciones Quimicas, Universidad \\ Autónoma del Estado de Hidalgo, Carretera Pachuca-Tulancingo, Kilómetro 4.5, Ciudad Universitaria, Pachuca de Soto, Hidalgo \\ 42074, México
}

(Received 17 October 2013; final version received 4 February 2014)

\begin{abstract}
The use of antimicrobials has increased the number of resistant bacteria to these drugs; however, the organic production has restricted the use of these compounds. The objectives of this work were to assess counts of tetracycline-resistant bacteria using conventional microbiology, to compare these results with those obtained for tet(A) and tet(B) genes by qPCR and to investigate both genes in conventional and organic meat. Counts of mesophilic aerobic bacteria were higher in organic beef, while chicken meat obtained higher counts for Enterobacteriaceae. Only tet(B) was higher in conventional pork and chicken meat than in their organic counterparts. The tet(A) gene was found in almost $100 \%$ of samples and tet(B) gene changed according to the type of meat. The presence of tet genes suggests that they are widely distributed, especially tet(A), in food of animal origin, even in organic meat samples obtained from animals in which the use of antimicrobials is restricted.
\end{abstract}

Keywords: tetracycline-resistance; meat; quantitative PCR; $\operatorname{tet}(\mathrm{A}) ; \operatorname{tet}(\mathrm{B})$

\begin{abstract}
El uso de los antimicrobianos ha incrementado sustancialmente el número de bacterias resistentes a estos fármacos sin embargo, la producción ecológica, ha limitado el uso de estos medicamentos. Los objetivos del trabajo fueron evaluar los recuentos obtenidos de bacterias resistentes a tetraciclina mediante microbiología convencional, obtener recuentos de bacterias con los genes tet(A) y tet(B) mediante qPCR e investigar la distribución de ambos genes en carne convencional y ecológica. Los recuentos de bacterias aerobias mesófilas fueron significativamente mayores en carne ecológica de ternera, mientras que los recuentos de Enterobacteriaceae fueron superiores en carne convencional de pollo. Sólo el gen tet(B) fue significativamente mayor en carne convencional de cerdo y de pollo que en sus homólogas ecológicas. El gen tet(A) se encontró en casi todas las muestras mientras que el tet(B) varió según la especie. La presencia de los genes tet sugiere que están ampliamente distribuidos, especialmente tet(A), en alimentos de origen animal, incluso en aquellos derivados de animales en los que el uso de antimicrobianos está seriamente restringido.
\end{abstract}

Palabras claves: resistencia a tetraciclina; carne; PCR cuantitativa; $\operatorname{tet}(\mathrm{A}) ; \operatorname{tet}(\mathrm{B})$

\section{Introduction}

Consumer interest in organic products has increased in recent years because this product type is often perceived to be healthier and safer than the products obtained from conventional farming (Magkos, Arvaniti, \& Zampelas, 2006; Young et al., 2009). Furthermore, conventional production is not favourably regarded because of the crowding conditions of the animals on the farms, which facilitates the appearance of infectious diseases and, therefore, encourages the disproportionate use of antimicrobial agents (Bailey \& Cosby, 2005).

The use of veterinary drugs in food-producing animals has become a major concern in food safety (Magkos et al., 2006). In particular, infectious diseases are traditionally treated with antimicrobial agents in animals, which contributes to the appearance of resistant bacteria that could contaminate the meat derived from these animals and pose a human health hazard through the food chain (Aarestrup, 2005; Hamer, Gerald, Friedman, \& Gill, 2002; Tollefson \& Karp, 2004). Moreover, another important factor in conventional production methods is the withdrawal period. This period is not always enough to reduce the resistant bacterial population (Enne, Livermore, Stephens, \& Hall, 2001; Khachatryan, Hancock, Besser, \& Call, 2004) because the adapted microbiota are difficult to replace by susceptible flora (Lipsitch \& Samore, 2002). Contrary to this type of animal rearing, the Regulation $889 / 2008 / \mathrm{EC}$ provides details of the restrictive rules for obtaining organic products, which are guaranteed by the community logo on the label of the product. Regarding sickness encountered in organic farming, synthetic allopathic medicines should be limited to the minimum possible and the withdrawal period must be twice that established for conventional production.

Due to the broad-spectrum activity against both gram-positive and gram-negative bacteria, the group of tetracyclines (TCs) has extended its use in animals and is one of the most used in Europe for the treatment of animal infections (Kools, Moltmann, \& Knacker, 2008). In Spain, in particular, the TCs were the bestselling antimicrobial family in 2009 (Ministerio de Sanidad, Servicios Sociales e Igualdad, 2011). The indiscriminate use of this agent has favoured the appearance and distribution of TCresistant bacteria (Chopra \& Roberts, 2001). Thus, the majority 
of the TC-resistance (tet) genes in bacteria have been associated with genetic mobile elements, such as plasmids, transposons and integrons, which facilitate the rapid dissemination of these genes among bacterial species (Chopra \& Roberts, 2001; Sunde \& Norstrom, 2006). With reduced antimicrobial selection pressure in organic farming, it is logical to assume that bacterial counts would be higher than in conventional meat, whereas higher TCresistant bacterial counts would be expected in conventional meat. In fact, this difference in the microbial contamination of meat has already been reported in other research (Miranda et al., 2007, 2009)

To the authors' knowledge, the direct quantification of all microbiota harbouring the $\operatorname{tet}(\mathrm{A})$ and the $\operatorname{tet}(\mathrm{B})$ genes has not been previously performed in organic meat samples. These genes are two of the most frequently found TC-resistance genes in gramnegative bacteria (Chopra \& Roberts, 2001). Thus, one aim of the present work was to quantify the bacteria harbouring the tet genes in conventional and organic meats by quantitative PCR (qPCR) Additionally, the results were compared to the TC-resistant mesophilic aerobic bacteria and Enterobacteriaceae counts obtained by conventional microbiological methods. This research strives to provide a global perspective regarding TC-resistant bacteria because tet genes are not solely transferred by pathogenic bacteria. A second objective was to study the frequency and distribution of the tet genes among different species and between conventional and organic meat. Despite the effort to obtain organic food, little is known about the pros and cons of this sort of production, and more comparative surveys should be conducted to support the theory that organic is safer than conventional farming.

\section{Materials and methods}

\section{Sample collection}

A total of 200 meat samples were analysed: pork steaks (40 conventional and 40 organic), chicken thighs (30 conventional and 30 organic) and beefsteaks (30 conventional and 30 organic). All samples were purchased from 15 supermarkets in Galicia (Spain) and 3 supermarkets and 2 organic retail stores in Madrid from March 2010 to March 2011.

The samples were purchased in different establishments, and all of them belonged to different batches. The samples were transported under refrigerated conditions to the laboratory and were analysed within $24 \mathrm{~h}$ of collection.

\section{Microbiological assays, sample preparation for qPCR}

Portions $(35 \mathrm{~g})$ from each sample were cut and added to $315 \mathrm{ml}$ buffered peptone water (Merck, Darmstadt, Germany) in a sterile bag with a lateral filter. The samples were homogenized in a masticator MIX 2 (AES, Combourg, France) for $2 \mathrm{~min}$. DNA was isolated from $200 \mu \mathrm{l}$ aliquots of the homogenates using the High Pure PCR Template Preparation Kit (Roche, Mannheim, Germany) according to the manufacturer's instructions for the isolation of nucleic acids from bacteria or yeast. After isolation, purified DNA was recovered in $50 \mu \mathrm{l}$ elution buffer and stored at $-20^{\circ} \mathrm{C}$ until PCR analysis.

The microbiological contamination $\left(\mathrm{CFU} \mathrm{g}^{-1}\right)$ of each sample was determined by pour plating dilutions $\left(10^{-1}\right.$ to $\left.10^{-6}\right)$ from $1 \mathrm{ml}$ aliquots of the homogenates. The Enterobacteriaceae contamination was determined by pour plating in violet red bile glucose agar (VRBG; Merck), and the total aerobic mesophilic counts were determined by pour plating in plate count agar (PCA; Merck). The same method was used to count TC-resistant Enterobacteriaceae and aerobic mesophilic bacteria by pour plating in VRBG and PCA, respectively, with the previous addition of TC $(16 \mathrm{mg} / \mathrm{l})$ (Sigma, St. Louis, MO, USA) (Clinical and Laboratory Standard Institute, 2005). Subsequently, the plates were incubated at $37^{\circ} \mathrm{C}$ for $24 \mathrm{~h}(\mathrm{VRBG})$ or $31^{\circ} \mathrm{C}$ for $72 \mathrm{~h}$ (PCA). After incubation, the pink-to-red colonies in VRBG were counted as Enterobacteriaceae, while all bacterial colonies grown in PCA were counted as aerobic mesophilic microorganisms and converted to $\log \mathrm{CFU} \mathrm{g} \mathrm{g}^{-1}$ units.

\section{Quantitative PCR conditions}

The primers and probes previously designed by Guarddon et al. (2010), and the Environmental Master Mix 2.0 (containing ROX as a passive reference), were obtained from Applied Biosystems (Warrington, UK). qPCR was performed using $25 \mu 1$ reaction volumes, which included $7.5 \mu \mathrm{l}$ template DNA, $12.5 \mu 1$ Environmental Master Mix, $900 \mathrm{nM}$ of each primer (forward and reverse) and $200 \mathrm{nM}$ Taqman probe. Amplification, detection and quantification were performed using an ABI PRISM 7000 Sequence Detection System (Applied Biosystems, Foster City, CA, USA). The following qPCR conditions were used: $10 \mathrm{~min}$ at $95^{\circ} \mathrm{C}$ for Taq-polymerase enzyme activation, followed by 40 cycles of $15 \mathrm{~s}$ at $95^{\circ} \mathrm{C}$ for denaturation and $1 \mathrm{~min}$ at $60^{\circ} \mathrm{C}$ for annealing and extension. The standard curves and the food samples were processed in duplicate. Negative controls, which consisted of the complete reaction except for template DNA, were included in all tests.

\section{Ouantification assays}

The standard curves were performed to quantify the bacteria that harboured the tet(A) gene; thus, a piece of each type of meat was artificially inoculated with Escherichia coli BM13 (C600 RifR)/ RP4) to create three different standard curves. Similarly, E. coli NCTC 50365 was used for the tet(B) gene. Both strains were grown at $41^{\circ} \mathrm{C}$ in VRBG for $24 \mathrm{~h}$. After incubation, brain-heart infusion (Difco, Detroit, MI, USA) tubes were inoculated with the isolated strains. The inoculated bacterial cultures were subsequently incubated at $31^{\circ} \mathrm{C}$ to obtain a concentration of $10^{9}$ CFU ml ${ }^{-1}$ as determined by a McFarland densitometer (Dinko, Barcelona, Spain) and confirmed by plate counting in PCA.

A portion of meat $(35 \mathrm{~g})$ was aseptically cut from the middle of the sample, added to $315 \mathrm{ml}$ buffered peptone water (Merck) in a sterile bag with a lateral filter and homogenized in a masticator for $2 \mathrm{~min}$. Then, eight tubes were filled with $9 \mathrm{ml}$ of the homogenate, and one of them was filled with $1 \mathrm{ml}$ of the saturated culture of $E$. coli BM13 (C600 RifR)/RP4. Subsequently, the standard curves were created from this inoculated tube by making 10 -fold serial dilutions in the remaining tubes until a range of $10^{1}$ to $10^{5} \mathrm{CFU} \mathrm{ml}^{-1}$ was covered, which corresponded to a final concentration of $10^{2}$ to $10^{6} \mathrm{CFU} \mathrm{g}{ }^{-1}$. The same protocol was repeated to create the standard curves from meat inoculated with the $E$. coli NCTC 50365 strain.

To quantify the TC-resistant bacteria, $35 \mathrm{~g}$ portions were cut from the meat samples and added to $315 \mathrm{ml}$ buffered peptone water in a sterile plastic bag with a lateral filter. All samples were homogenized in a masticator for $2 \mathrm{~min}$. Two non-inoculated aliquots were also analysed as negative controls.

DNA was isolated from a $200 \mu 1$ aliquot of each dilution or sample and was stored at $-20^{\circ} \mathrm{C}$. After the qPCR reaction, the cycle threshold $\left(C_{\mathrm{T}}\right)$ was plotted against the log concentration of the template DNA. The obtained results were expressed in log 
Table 1. Mean counts of mesophilic aerobic bacteria (MA), Enterobacteriaceae (EB), TC-resistant mesophilic aerobic bacteria (MATE) and TC-resistant Enterobacteriaceae (EBTE) and the total counts of bacteria harbouring the tet genes in organic and conventional chicken meat, beef and pork, expressed in $\log$ CFU g ${ }^{-1}$.

Tabla 1. Medias de los recuentos de bacterias aerobias mesófilas (MA), Enterobacteriaceae (EB), bacterias aerobias mesófilas resistentes a tetraciclina (MATE), Enterobacteriaceae resistentes a tetraciclina (EBTE) y recuento total de bacterias con los genes tet en carne ecológica y convencional de pollo, ternera y cerdo, expresados en $\log \mathrm{CFU} \mathrm{g}^{-1}$.

\begin{tabular}{|c|c|c|c|c|c|c|c|c|}
\hline \multirow[b]{2}{*}{ Production method } & \multirow[b]{2}{*}{ Meat samples } & \multicolumn{7}{|c|}{ Counts (log CFU g $\left.{ }^{-1}\right)$} \\
\hline & & $\mathrm{EB}^{\mathrm{a}}$ & EBTE $^{a}$ & $\mathrm{MA}^{\mathrm{a}}$ & MATE $^{\mathrm{a}}$ & $\operatorname{tet}(\mathrm{A})^{\mathrm{b}}$ & $\operatorname{tet}(\mathrm{B})^{\mathrm{b}}$ & $\operatorname{tet}(\mathrm{A})+\operatorname{tet}(\mathrm{B})^{\mathrm{b}}$ \\
\hline \multirow[t]{3}{*}{ Organic } & Chicken (30) & 2.8 & 1.8 & 4.7 & 3.7 & 2.7 & 1.8 & 2.8 \\
\hline & Beef (30) & 3.4 & 1.8 & 5.9 & 5.1 & 2.4 & 2.9 & 3.2 \\
\hline & Pork (40) & 2.8 & 1.7 & 5.1 & 4.2 & 2.7 & 2.7 & 3.1 \\
\hline \multirow[t]{3}{*}{ Conventional } & Chicken (31) & 3.7 & 2.1 & 5.3 & 4.3 & 2.8 & 2.8 & 3.3 \\
\hline & Beef (30) & 3.0 & 1.8 & 5.0 & 4.0 & 2.8 & 2.7 & 3.3 \\
\hline & Pork (40) & 3.0 & 1.7 & 4.7 & 4.0 & 2.5 & 3.2 & 3.4 \\
\hline
\end{tabular}

Note: ${ }^{a}$ Plate count technique; ${ }^{\mathrm{b}} \mathrm{qPCR}$.

$\mathrm{CFU} \mathrm{\textrm {g } ^ { - 1 }}$. The standard curves and samples were made in duplicate, and the averaged $C_{\mathrm{T}}$ values were calculated in all cases.

\section{Statistical analysis}

Student's $t$-test was used to compare the counts that were obtained by qPCR and by conventional microbiological methods. The differences were considered statistically significant when $p<0.05$. $\chi^{2}$ Pearson test was also used to assess the relationship between the conventional and organic meat and the presence of the $\operatorname{tet}(\mathrm{A})$ and $\operatorname{tet}(\mathrm{B})$ genes in those types of meat. All analyses were performed using Predictive Analytics Software (PASW) (version 18.0) (IBM, Chicago, IL, USA).

\section{Results and discussion}

Mesophilic aerobic bacteria, Enterobacteriaceae, TC-resistant mesophilic aerobic bacteria and Enterobacteriaceae and bacteria harbouring the $\operatorname{tet}(\mathrm{A})$ and/or tet $(\mathrm{B})$ genes were counted (Table 1). In all cases, the global microbiological counts were significantly higher in normal media than in media supplemented with TC. In contrast, there were no differences when comparing conventional with organic meat, with the exception of beef, where the counts of mesophilic aerobic bacteria and resistant mesophilic aerobic bacteria were significantly higher in organic meat. However, in chicken meat, the Enterobacteriaceae counts were only significantly higher in conventional meat.

Few articles have compared mesophilic aerobic bacteria and Enterobacteriaceae plate counts in meat samples, and even fewer have compared these microbiota in media supplemented with TC. In the present work, the results in organic beef meat confirmed that bacterial contamination in organic food is often higher than that obtained from their conventionally produced counterparts (Bailey \& Cosby, 2005; Magkos et al., 2006; Miranda et al., 2008). However, no significant differences were found in the case of the Enterobacteriaceae counted in beef. Furthermore, Miranda et al. (2009) did not find differences between organic and conventional beef, although they made this comparison exclusively in pathogenic strains and not in all microbiota. Contrary to the beef experiments, the results of the Enterobacteriaceae counts in chicken meat are different than the results obtained by Miranda et al. (2008), who found higher counts of Enterobacteriaceae but less antimicrobial resistance in organic poultry meat. Because TC-resistant strains and resistance genes are becoming more widely distributed in the environment, this prevalence could explain the lack of significant differences between both types of farming.

In fact, many authors have assessed the tet genes in different kinds of samples, but little is known about the direct quantification of bacteria harbouring these genes. Although E. coli is frequently studied following isolation from clinical samples (Schwaiger, Holzel, \& Bauer, 2010) or from food of animal origin (Jouini et al., 2009), there are no investigations that can offer a global overview of all microbiota that carry tet(A) and/or tet(B) genes in food samples. In this work, the authors applied the Taqman qPCR method described by Guarddon et al. (2011) in different types of meat.

Standard curves were created to quantify bacteria harbouring the $\operatorname{tet}(\mathrm{A})$ and $\operatorname{tet}(\mathrm{B})$ genes using pork, beef and chicken meat as matrices. A linear relationship between $\log$ input $\mathrm{CFU} \mathrm{g^{-1 }}$ and $C_{\mathrm{T}}$ was observed in all cases. To calculate the amount of bacteria with a tet gene, each type of meat was inoculated with $E$. coli BM13 (C600 RifR)/RP4 and E. coli NCTC 50365 to calculate the presence of tet(A) and tet(B), respectively. Consequently, the standard curve for tet(A) in pork had a slope of -3.02 and a square regression coefficient $\left(R^{2}\right)$ of 0.9879 , whereas tet $(\mathrm{B})$ had a slope of -3.01 and an $R^{2}$ coefficient of 0.9656 . Chicken meat inoculated in the same manner exhibited different results. For tet (A), the slope was -3.53 and the $R^{2}$ coefficient was 0.9983 , whereas the slope was -3.09 for $\operatorname{tet}(\mathrm{B})$ and the $R^{2}$ coefficient was 0.9470 . Finally, the beef standard curve had a slope of -3.17 and an $R^{2}$ coefficient of 0.9937 for $\operatorname{tet}(\mathrm{A})$ and a slope of -3.05 and an $R^{2}$ coefficient of 0.9963 for tet $(\mathrm{B})$.

The linearity of standard curves decreased below $5 \times 10^{2}$ $\mathrm{CFU} \mathrm{g}{ }^{-1}$ when the calculations were performed in the aforementioned food matrices. Therefore, minimal amounts of the tested genes could be detected; however, the quantification was not as accurate as desired. Thus, the authors established the limit of detection (LOD) to be $5 \times 10^{2} \mathrm{CFU} \mathrm{g}^{-1}$ to allow more precise quantification.

The amount of bacteria harbouring $\operatorname{tet}(\mathrm{A})$ and $\operatorname{tet}(\mathrm{B})$ genes was evaluated among the different types of meat, and the results showed that the tet(A) gene was detected in almost $100 \%$ of the samples. However, the presence of $\operatorname{tet}(\mathrm{B})$ changed according to the tested species. This corroborates other research that also found the $\operatorname{tet}(\mathrm{A})$ gene more frequently than $\operatorname{tet}(\mathrm{B})$ in porcine $E$. coli (Lanz, Kuhnert, \& Boerlin, 2003; Schwaiger et al., 2010), E. coli isolated from foods of animal origin (Jouini et al., 2009), $E$. coli isolated from food animals (Sengelov, Halling-Sorensen, \& 
Aarestrup, 2003) or gram-negative clinical isolates (Fan, Hamilton, Webster-Sesay, Nikolich, \& Lindler, 2007). Guarddon, Miranda, Vázquez, Cepeda, and Franco (2012) also detected more tet( $\mathrm{A})$ genes than $\operatorname{tet}(\mathrm{B})$ in conventional meat. Nevertheless, these rates changed regarding the LOD of the genes. The tet(A) gene was only more frequent in chicken meat, whereas pork and beef showed greater percentages of bacteria with the $\operatorname{tet}(\mathrm{B})$ gene. These results differ from those obtained by the cited authors. However, it must be considered that the data presented in this work are obtained from the total microbiota in the meat samples rather than from isolates, which offers a different perspective on the bacteria that harbour these genes. This is a highly relevant issue because these kinds of genes are transferred from many different genera and species of bacteria and not solely from pathogens such as $E$. coli; therefore, these microorganisms can also reach humans through the food chain.

The counts of bacteria harbouring the $\operatorname{tet}(\mathrm{A})$ and/or $\operatorname{tet}(\mathrm{B})$ genes were also compared between conventional and organic meat. These results revealed that only $\operatorname{tet}(\mathrm{B})$ was significantly higher in conventional pork and chicken meat compared to the organic meat. The counts for both genes $(\operatorname{tet}(\mathrm{A})+\operatorname{tet}(\mathrm{B}))$ were significantly higher in conventional chicken meat as well. These differences are shown in Figure 1, where the box plot represents the results of the concentrations of counts of TC-resistant bacteria in five different groups: TC-resistant mesophilic aerobic bacteria, TC-resistant Enterobacteriaceae, bacteria harbouring the $\operatorname{tet}(\mathrm{A})$ gene, bacteria harbouring the $\operatorname{tet}(\mathrm{B})$ gene and bacteria harbouring both the tet genes. The values of $\operatorname{tet}(\mathrm{A})$ above the median are more distributed than those reached by tet(B), for which the data are more concentrated in low values. Surprisingly, these results can be found in animal species in which the frequency of the $\operatorname{tet}(\mathrm{A})$ gene is lower, despite the high quantity of the gene. Therefore, the authors emphasize that the percentage of strains with tet genes can differ from the amount in the sample. Thus, in conventional beef, the average amount of bacteria harbouring $\operatorname{tet}(\mathrm{A})$ was $2.8 \log \mathrm{CFU} \mathrm{g}{ }^{-1}$ with $36.67 \%$ of the samples over the LOD versus $2.7 \log$ CFU g ${ }^{-1}$ with $53.33 \%$ of the $\operatorname{tet}(\mathrm{B})$ gene. This difference may be due to the number of copies of the gene in each bacterium because they are encoded on plasmids, and therefore, the tet $(\mathrm{B})$ gene could be present at a lower number per cell than tet(A), as observed by Fan et al. (2007).

On the other hand, the frequency of the tet genes was also assessed in all analysed types of meat. Regardless of the type of
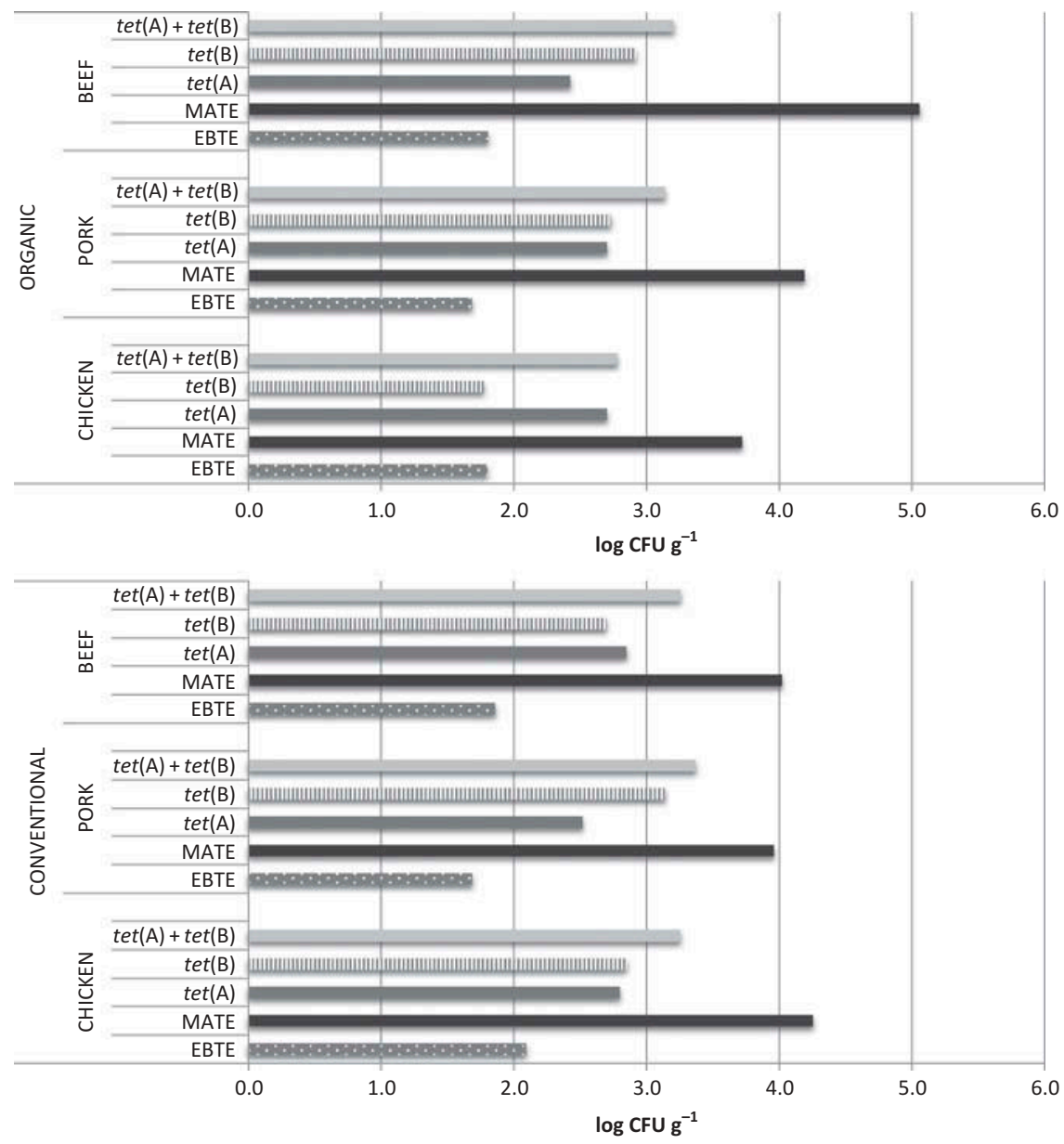

Figure 1. Counts of TC-resistant bacteria in conventional and organic meat samples. This graphic shows a comparison of the counts of TC-resistant mesophilic aerobic bacteria (MATE), TC-resistant Enterobacteriaceae (EBTE) and bacteria harbouring the tet(A) and/or tet(B) genes between organic and conventional beef, pork and chicken meat (expressed in $\log \mathrm{CFU} \mathrm{g}{ }^{-1}$ ).

Figura 1. Recuentos de bacterias resistentes a tetraciclina en carne convencional y ecológica. Los gráficos muestran una comparación de recuentos de bacterias aerobias mesófilas resistentes a tetraciclina (MATE), Enterobacteriaceae resistentes a tetraciclina (EBTE) y de bacterias portadoras de los genes tet(A) y/o tet(B)entre carnes convencionales y ecológicas de ternera, cerdo y pollo (expresados en log CFU $\mathrm{g}^{-1}$ ). 
Table 2. The number and percentages of samples with bacteria harbouring tet(A), tet(B) and both tet genes, over the LOD, in organically and conventionally produced pork, beef and chicken meat.

Tabla 2. Número y porcentaje de muestras con bacterias portadoras de los tet(A), tet(B) y ambos genes, por encima del LOD, en carne de cerdo, ternera y pollo producidas de forma convencional y ecológica.

\begin{tabular}{|c|c|c|c|c|c|c|}
\hline \multirow{2}{*}{$\begin{array}{l}\text { Genes } \\
\text { Meat samples }\end{array}$} & \multicolumn{2}{|c|}{$\operatorname{tet}(\mathrm{A})$} & \multicolumn{2}{|c|}{$\operatorname{tet}(\mathrm{B})$} & \multicolumn{2}{|c|}{$\operatorname{tet}(\mathrm{A})+\operatorname{tet}(\mathrm{B})$} \\
\hline & Organic & Conventional & Organic & Conventional & Organic & Conventional \\
\hline Pork (40 O; $40 \mathrm{C})$ & $17(42.5)$ & $18(45.0)$ & $14(35.0)$ & $27(67.5)$ & $23(57.5)$ & $40(100.0)$ \\
\hline Beef $(30 \mathrm{O} ; 30 \mathrm{C})$ & $11(36.7)$ & $11(36.7)$ & $19(63.3)$ & $16(53.3)$ & $22(73.3)$ & $24(80.0)$ \\
\hline Chicken $(30 \mathrm{O} ; 31 \mathrm{C})$ & $13(43.3)$ & $13(41.9)$ & $2(6.7)$ & $18(58.1)$ & $12(40.0)$ & $28(90.2)$ \\
\hline
\end{tabular}

Note: $\mathrm{O}=$ organic; $\mathrm{C}=$ conventional.

animal production, the tet(A) gene was found in approximately $100 \%$ of the samples, whereas the detection of the tet $(\mathrm{B})$ gene changed according to the sort of meat. Thus, this gene was detected in organic $(76 \%)$ and conventional $(70.9 \%)$ chicken meat, organic $(95 \%)$ and conventional $(55 \%)$ pork meat and organic $(83.3 \%)$ and conventional $(96.7 \%)$ beef. The percentages of samples that showed the presence of the cited genes over the LOD are represented in Table 2.

The use of antimicrobials, such as TC, in clinical practices acts as a selective pressure that may increase drug resistance and the variety of resistance genes in the environment (Smith et al., 2007). Considering the specifications of the Regulation 889/2008/EC for organic production and, particularly, the restrictions on the use of antimicrobials, differences depending on the farming method were expected in the amount of bacteria that would be found to harbour the $\operatorname{tet}(\mathrm{A})$ and the $\operatorname{tet}(\mathrm{B})$ genes. Thus, counts of bacteria with the $\operatorname{tet}(\mathrm{B})$ gene were significantly greater in conventional pork and chicken meat than in organic meats. These differences were also observed when both genes were present in the same species. These differences seem to be related to the farming method; however, beef samples did not show the expected results because no differences were found for any of the tested genes. Surprisingly, in several studies, the prevalence of antimicrobial resistance genes could be not related to the use of veterinary antimicrobials (Enne et al., 2001; Khachatryan et al., 2004; Smith et al., 2007). In fact, Smith et al. (2007) observed a high prevalence of resistance to antimicrobial agents that are not frequently used in chicken husbandry. Khachatryan et al. (2004) related the high rate of resistant bacteria to the age of the animal, finding this relationship greater in younger calves independent of antimicrobial administration.

In conclusion, many factors can influence the prevalence of drug resistance in bacteria found in food of animal origin. This type of study may serve to warrant food security and to let the consumer know if organic products are actually better than conventional products. Furthermore, it would inform the consumer whether the purchase of organic products is worth the high price at the market. In this work, the results have shown a lack of microbiological differences between organic and conventional meat, and because of that, the authors cannot conclude that organic is better than conventional meat for the studied parameters. As suggested by Magkos et al. (2006), diseases in farming animals are inevitable. Although in organic production homeopathic treatment has priority in the case of sickness, allopathic medicines are not banned; so it is possible that antimicrobial agents are used more than expected. However, it should be noted that the withdrawal period, which is doubled in organic farming, is not enough to remove the TCresistance genes in meat bacteria, and qPCR could be a useful tool for monitoring the presence of these genes.
Moreover, because of the obtained results, the authors propose the improvement of not only hygiene practices in farms but also surveillance in animal production, particularly in the use of antimicrobial agents. Nevertheless, the data for the frequency and amount of tet genes also suggest that they are widely distributed, especially tet(A), in food of animal origin. These genes are even present in organic food originating from animals in which the use of antimicrobial treatment is seriously restricted.

\section{Acknowledgements}

The authors are grateful to the Institute Pasteur for providing the E. coli BM13 (C600 RifR)/RP4 strain $(\operatorname{tet}(\mathrm{A}))$ and to the Health Protection Agency for providing the E. coli NCTC 50365 strain (tet(B)). Xunta de Galicia (project 09MRU010261PR) supported this work. We also thank Carmen Carreira and Rodrigo García for their technical support.

\section{References}

Aarestrup, F. M. (2005). Veterinary drug usage and antimicrobial resistance in bacteria of animal origin. Basic Clinical Pharmacology Toxicology, 96(4), 271-281. doi:10.1111/j.1742-7843.2005. pto960401.x

Bailey, J., \& Cosby, D. (2005). Salmonella prevalence in free-range and certified organic chickens. Journal of Food Protection, 68(11), 2451-2453.

Chopra, I., \& Roberts, M. (2001). Tetracycline antibiotics: Mode of action, applications, molecular biology, and epidemiology of bacterial resistance. Microbiology and Molecular Biology Reviews, 65(2), 232-260. doi:10.1128/MMBR.65.2.232-260.2001

Clinical and Laboratory Standard Institute. (2005). Performance standards for antimicrobial susceptibility testing. 15th informational supplemented M100-S15. Wayne, PA: CLSI.

Commission Regulation (EC) no 889/2008 of 5 September 2008 laying down detailed rules for the implementation of Council Regulation (EC) no 834/2007 on organic production and labelling of organic products with regard to organic production, labelling and control.

Enne, V., Livermore, D., Stephens, P., \& Hall, L. (2001). Persistence of sulphonamide resistance in Escherichia coli in the UK despite national prescribing restriction. The Lancet, 357(9265), 1325-1328. doi:10.1016/S0140-6736(00)04519-0

Fan, W., Hamilton, T., Webster-Sesay, S., Nikolich, M. P., \& Lindler, L. E. (2007). Multiplex real-time SYBR green IPCR assay for detection of tetracycline efflux genes of gram-negative bacteria. Molecular and Cellular Probes, 21(4), 245-256. doi:10.1016/j.mcp.2006.12.005

Guarddon, M., Miranda, J. M., Franco, C. M., Martínez, B., Váquez, B. I., \& Cepeda, A. (2010). Mètodos y reactivos para la detección y cuantificación de bacterias resistentes a tetraciclinas. Spanish patent application P201030856

Guarddon, M., Miranda, J. M., Rodríguez, J. A., Vázquez, B. I., Cepeda, A., \& Franco, C. M. (2011). Real-time polymerase chain reaction for the quantitative detection of tetA and tetB bacterial tetracycline resistance genes in food. International Journal of Food 
Microbiology, 146(3), 284-289. doi:10.1016/j. ijfoodmicro.2011.02.026

Guarddon, M., Miranda, J. M., Vázquez, B. I., Cepeda, A., \& Franco, C M. (2012). Direct quantification and distribution of tetracyclineresistant genes in meat samples by real-time polymerase chain reaction. Journal of Food Science, 77(7), M372-M376. doi:10.1111/ j.1750-3841.2012.02777.x

Hamer, D., Gerald, J., Friedman, D., \& Gill, C. (2002). From the farm to the kitchen table: The negative impact of antimicrobial use in animals on humans. Nutrition Reviews, 60(8), 261-264. doi:10.1301/ 002966402320289395

Jouini, A., Ben Slama, K., Saenz, Y., Klibi, N., Costa, D., Vinue, L., ..., Torres C. (2009). Detection of multiple-antimicrobial resistance and characterization of the implicated genes in Escherichia coli isolates from foods of animal origin in Tunis. Journal of Food Protection, 72(5), 1082-1088.

Khachatryan, A., Hancock, D., Besser, T., \& Call, D. (2004). Role of calf-adapted Escherichia coli in maintenance of antimicrobial drug resistance in dairy calves. Applied and Environmental Microbiology 70(2), 752-757. doi:10.1128/AEM.70.2.752-757.2004

Kools, S. A. E., Moltmann, J. F., \& Knacker, T. (2008). Estimating the use of veterinary medicines in the European Union. Regulatory Toxicology and Pharmacology, 50(1), 59-65. doi:10.1016/j.yrtph.2007.06.003

Lanz, R., Kuhnert, P., \& Boerlin, P. (2003). Antimicrobial resistance and resistance gene determinants in clinical Escherichia coli from different animal species in Switzerland. Veterinary Microbiology, 91(1), 73-84. doi:10.1016/S0378-1135(02)00263-8

Lipsitch, M. \& Samore, M. (2002). Antimicrobial use and antimicrobia resistance: A population perspective. Emerging Infectious Diseases, 8(4), 347-354. doi:10.3201/eid0804.010312

Magkos, F., Arvaniti, F., \& Zampelas, A. (2006). Organic food: Buying more safety or just peace of mind? A critical review of the literature. Critical Reviews in Food Science and Nutrition, 46(1), 23-56. doi:10.1080/10408690490911846

Ministerio de Sanidad, Servicios Sociales e Igualdad. Datos de ventas de antimicrobianos en veterinaria año 2009. [Internet]. Updated 4th May 2011. Retrieved September 14, 2012, from http://www.aemps.gob.es/ informa/notasInformativas/medicamentos Veterinarios/2011/home.htm

Miranda, J. M., Guarddon, M., Mondragon, A., Vazquez, B. I., Fente, C. A., Cepeda, A., ..., Franco, C. M. (2007). Antimicrobial resistance in Enterococcus spp. strains isolated from organic chicken, conventional chicken, and turkey meat: A comparative survey. Journal of Food Protection, 70(4), 1021-1024.

Miranda, J. M., Guarddon, M., Vázquez, B. I., Fente, C. A., BarrosVelázquez, J., Cepeda, A., ..., Franco C. M. (2008). Antimicrobial resistance in Enterobacteriaceae strains isolated from organic chicken, conventional chicken and conventional turkey meat: A comparative survey. Food Control, 19(4), 412-416. doi:10.1016/j. foodcont.2007.05.002

Miranda, J. M., Mondragón, A., Vázquez, B. I., Fente, C. A., Cepeda, A., \& Franco, C. M. (2009). Influence of farming methods on microbiological contamination and prevalence of resistance to antimicrobial drugs in isolates from beef. Meat Science, 82(2), 284-288. doi:10.1016/j.meatsci.2009.01.020

Schwaiger, K., Holzel, C., \& Bauer, J. (2010). Resistance gene patterns of tetracycline resistant Escherichia coli of human and porcine origin. Veterinary Microbiology, 142(3-4), 329-336.

Sengelov, G., Halling-Sorensen, B., \& Aarestrup, F. (2003). Susceptibility of Escherichia coli and Enterococcus faecium isolated from pigs and broiler chickens to tetracycline degradation products and distribution of tetracycline resistance determinants in $E$. coli from food animals. Veterinary Microbiology, 95(1-2), 91-101.

Smith, J. L., Drum, D. J. V., Dai, Y., Kim, J. M., Sanchez, S., Maurer, J. J....., Lee M. D. (2007). Impact of antimicrobial usage on antimicrobial resistance in commensal Escherichia coli strains colonizing broiler chickens. Applied and Environmental Microbiology, 73(5), 1404-1414. doi:10.1128/AEM.01193-06

Sunde, M., \& Norstrom, M. (2006). The prevalence of, associations between and conjugal transfer of antibiotic resistance genes in Escherichia coli isolated from Norwegian meat and meat products. Journal of Antimicrobial Chemotherapy, 58(4), 741-747. doi:10.1093/jac/dk1294

Tollefson, L., \& Karp, B. E. (2004). Human health impact from antimicrobial use in food animals. Médecine et Maladies Infectieuses, 34(11), 514-521. doi:10.1016/j.medmal.2004.07.028

Young, I., Rajić, A., Wilhelm, B. J., Waddell, L., Parker, S., \& McEwen, S. A. (2009). Comparison of the prevalence of bacterial enteropathogens, potentially zoonotic bacteria and bacterial resistance to antimicrobials in organic and conventional poultry, swine and beef production: A systematic review and meta-analysis. Epidemiology and Infection, 137(9), 1217-1232. doi:10.1017/ S0950268809002635 